Our Nature (2005) 3:1-12

\title{
Revisiting Underlying Ecological Principles of Rice-Fish Integrated Farming for Environmental, Economical and Social benefits
}

\author{
T.B. Gurung and S.K. Wagle \\ Nepal Agriculture Research Council (NARC) \\ Fisheries Research Station, Pokhara Lake Side, Baidam, Nepal \\ E-mail:fishres@fewanet.com.np
}

\begin{abstract}
Our goal is to revisit underlying ecological principle of rice-fish farming integration and synthesize information to suggest some pertinent patterns and connections that contribute to understanding of the interactions of abiotic and biotic factors in rice field for productivity enhancement. We synthesized ecological interactions, energy and material flow in absence and presence of bottom feeding omnivore fish to give a clear scenario of food web interactions in rice field. Rice plants, weeds and minute algae can be competitive to each other as they depend on common resources for growth. However, introduction of the fish about two weeks after rice plantation can add new link to the food chain by perturbation and top down control on rice competitors, pests and mobility of nutrients towards rice plant for increased rice field productivity to benefit the farmers economically, environmentally and socially.

In relation to above synthesis, rice-fish integrated field experiments were performed in 4 mid hill districts of Nepal from 2000-2002. The results showed that despite of 3-5\% loss of the rice cultivating area due to "trench" as fish hiding place, rice yield increased up to $9 \%$ in addition of $529 \mathrm{~kg} \mathrm{ha}^{-1}$ fish from rice-fish integrated farming than cultivating rice alone. In rice-fish system, competitive advantages of rice plants over weeds and micro algae, control on rice pest and increased nutrient supply due to top down, perturbation and nutrient regeneration by fish were the reasons of increased rice yield in treatments than in controls where rice alone was cultivated.
\end{abstract}

Key Words: Ecological principle, Rice-Fish integrated farming, Social benefit

\section{Introduction}

Rice, Oryza sativa L., is one of the most fish in rice field might have influenced the dominant crops and major source of idea of rice-fish farming for enhancing prolivelihood for many poor producers and ductivity.

consumers in Asia (De la Cruz et al., 1992; Rice-fish farming is most advanced in Rothuis, 1998; Barker and Dawe, 2000). In China, producing 377,000 tons of fish from general, rice require substantial amount of rice field in 1996 (Halwart, 1998). A variety water for farming. Due to abundant water, of fish species can be integrated with rice, many fish species prefer the rice field for such as common carp (Cyprinus carpio), their reproduction and growth (Li, 1988; Ali, catfish (Clarias batrachus), silver barb 1992; Fernando, 1993; Little et al., 1996; (Puntius gonionotus), major carps, tilapia, Halwart, 1998). Such natural aggregation of prawn etc. in rice field (Dutta et al., 1986; 
T.B. Gurung and S.K. Wagle / Our Nature (2005)3:1-12

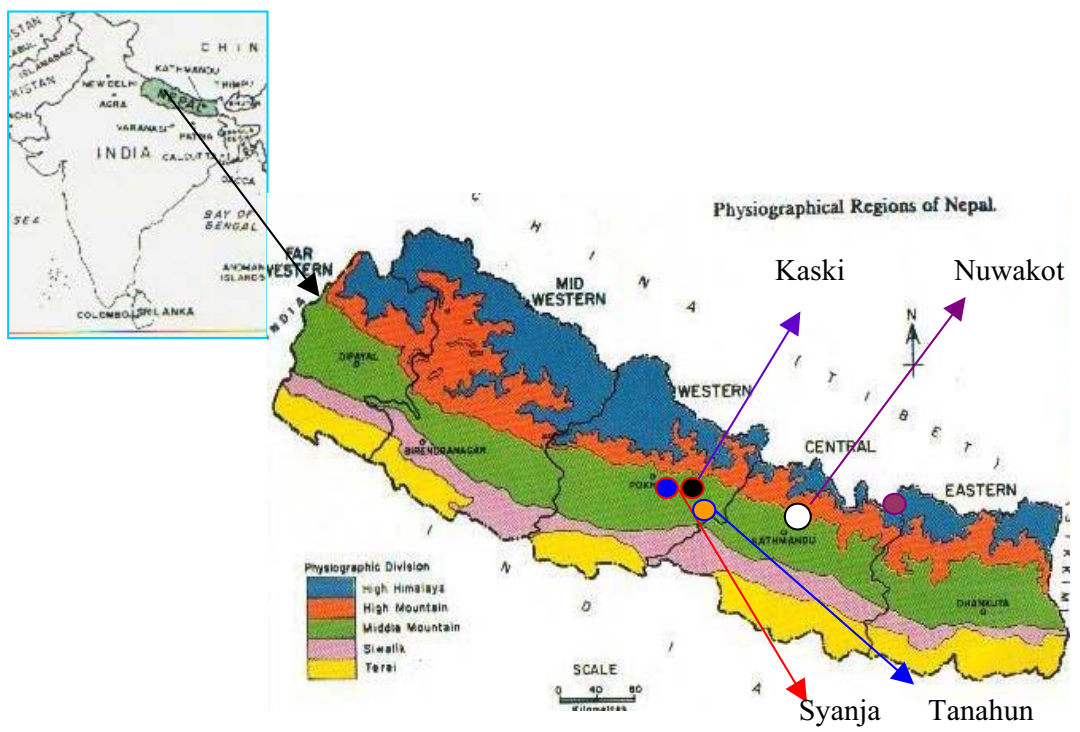

Figure.1. Location of the experimental areas in mid hills of Nepal

Halwart, 1998; Surtida, 2000).

Rice and fish are one of the main staple foods for most people of Asia, where food deficiency is one of the crucial issues. On addition, abuses of insecticides have been the problems for sustainable agriculture productivity (Koesoemadinata, 1980; Cagauan and Arce, 1992; Gyawali, 1999; Matteson, 2000).

Rice-fish farming is one of the best options to increase the food production from limited land through ecological agriculture (Jintong, 1996; Sugen et al., 1996; De la Cruz, 1994). This attributes to an environment friendly rice-fish farming for increase productivity by recycling the energy and matter in sustainable manner (Coche, 1967; Xieping et al., 1996; Edwards, 2000).

Here, on the basis of present knowledge, we present a theoretical synthesis and evidences of ecological process: how energy and matter are mobilized and recycled in rice-fish integration to benefit the rice field productivity.

\section{Materials and Methods}

This study was conducted in farmer's field at Syangja, Kaski, Tanahun and Nuwakot districts of Nepal (Figure 1). In Syangja and Tanahun, experiment on fish stocking density, in Kaski suitable rice cultivar; and in Nuwakot fertilizers and feeding rates on fish production were examined. All the experimental plots ranging from $100-150 \mathrm{~m}^{2}$ were located at about 600 to $700 \mathrm{~m}$ elevation (mid hill region) from the sea level. Slight modification of plots were made according to Figure 2a, where dike were improved to maintain the base $0.5 \mathrm{~m}$, top width $0.3 \mathrm{~m}$ and height $0.4 \mathrm{~m}$. Similarly, in each treatment, trench dimension was maintained $0.4-0.5 \mathrm{~m}$ 


\section{T.B. Gurung and S.K. Wagle / Our Nature (2005)3:1-12}

wide and $0.4-0.5 \mathrm{~m}$ deep as shelter to fish during emergencies. The area covered by trench was about $3-5 \%$ of the experimental rice plots.

At the inlet and outlet, a wire net screen of $1 / 4 "$ mesh mounted on wooden frame was fixed (Figure $2 \mathrm{~b}$ ). Field preparation began by ploughing and harrowing as per farmer's practice. A total dose of inorganic nitrogen, phosphorus and potash at $50.0 \mathrm{~kg} \mathrm{ha}^{-1}, 30.0$ $\mathrm{kg} \mathrm{ha}^{-1}$ and $30 \mathrm{~kg} \mathrm{ha}^{-1}$ were applied. Out of the total, $50 \%$ was used during field preparation as basal dose; remaining $50 \%$ was divided into two doses for top dressing at the time of flowering and panicle initiation. Water filling was started after fixing the screens.

For reliability of the rice varieties, seeds were obtained from Agronomy Section of NARC (Nepal Agricultural Research Council) and seedlings were germinated by farmers. A method of straight row planting at 20-25 cm between rows and hills with 3-4 seedlings hills ${ }^{-1}$ was followed. Water level was maintained at $8-10 \mathrm{~cm}$ in first 30 days and later gradually increases up to $15-20 \mathrm{~cm}$ till fish harvest.

\section{Fish Integration}

Fish used for integration was common carp, Cyprinus carpio. Fish were stocked after 1015 days of rice plantation. In general, feeding at the rate of $2 \%$ body weight of stocked fish was started next day after fingerlings stocking, except special care was given according to experimental designs for feeding. The feed ingredients were (i) rice bran $50.0 \%$, (ii) wheat bran $10.0 \%$ (iii) oil cake powder $40.0 \%$. These ingredients were mixed and moist balls were prepared which were put everyday at the same place on the base of the trench. The experiment was continued for about 88-95 days. During this period growth check was performed once in a month by weighing about $1 / 3$ population of stocked fish. Fish were finally harvested 2weeks prior of rice harvesting.

The inlet and outlet screens were cleaned every day. Dikes were checked and maintained. To measure the growth of rice, random sampling using $1 \mathrm{~m} \times 1 \mathrm{~m}$ quadrate was performed. Tiller from rice plants within the quadrate were counted at an interval of 15-30 days till a nearly constant value was reached. Weeding was carried after 20,30, 45 and $60^{\text {th }}$ day after transplantation. Disease and pest were monitored. Rice yield data were taken by harvesting rice in $1 \mathrm{~m}$ long and $1 \mathrm{~m}$ wide bamboos split quadrate.

\section{Fish density vs. size experiments}

In this study stocking rate of 4000,5000 , and 6000 fingerlings ha ${ }^{-1}$ have been considered as low density (LD), medium density (MD) and high density (HD), respectively. Initial average body weight of 5-10 g and 15-20 g fingerling was considered as small size (SS) and large size (LS), respectively. The treatments identified were low density: small size (LD: SS), medium density: large size (LD: LS), medium density: small size (MD: SS), high density: small size (HD: SS), and high density: large size (HD: LS). The rice cultivar used in the experiment was Sabitri. In control (C) only rice was planted without trench and fish. All treatments and control were replicated.

\section{Feeding and fertilization experiment at Nuwakot}

The stocking rate of fish was 6000 fingerlings $\mathrm{ha}^{-1}$ with an average size of 5-10 $\mathrm{g}$ in all treatments. The feeding rate examined were $0 \%, 2 \%, 4 \%$ of the total body weight of stocked fish. The rice variety used was 


\section{T.B. Gurung and S.K. Wagle / Our Nature (2005)3:1-12}

Janaki. All the treatments and control were replicated. In control and treatment, the dose of inorganic fertilizer (In) was same as described earlier, while organic (Or) fertilizer (farm yard manure) was used at the rate of $7000 \mathrm{~kg} \mathrm{ha}^{-1}$, with a basal dose used was at $3000 \mathrm{~kg} \mathrm{ha}^{-1}$. The remaining dose was used for top dressing (four times) at 15 days interval after rice plantation.

\section{Rice cultivar experiment at Kaski}

In this experiment Mansuli (M), Sabitri (S) and Radha-4 (R) rice cultivars were tested for their performance in combination with fish. With all rice cultivars, controls were without fish, while two: (i) organic and (ii) inorganic fertilizers treatments possessed 5-10 g body weight individual fish at the density of 6000 $\mathrm{ha}^{-1}$. All controls and treatments were replicated.

\section{Result and Discussion}

Our results agreed with the findings of previous studies, where it has been shown that productivity of rice field increased by integrated farming of rice and fish together in the same field (Arce and De la Cruz, 1978; Middendrop and Verreth, 1986; Dewan, 1992; Torres et al., 1992; Xu and Yixian, 1992; Cagauan, 1994; Dasu and Jiangu, 1996). It is known that interrelationship between abiotic and biotic factors play vital role on final product of food chain and has direct impact on net output of ecosystem. The primary source of energy accumulation in plants is through absorbing solar energy, $\mathrm{CO}_{2}$, nutrients for photosynthesis.

The abiotic and biotic components of rice fields are shown in Figure 3 as described in many previous studies (Jintong, 1996; Sugen et al., 1996). Here, pests are rice enemies, weeds and micro algae are competitors for resources; and nutrients may assume in immobile state (Figure 3A) comparing to where a bottom feeding omnivore, common carp is present (Figure 3B). Thus, if the fish with bottom feeding capabilities are introduced, they add new link to the food chain by top down control and bioperturbation on rice competitors, pests, parasites and on mobility of the nutrients towards the rice plant (Figure 3B).

Rice-fish integration is one of the best examples of commensalisms, where both rice and fish are benefited for increased productivity of rice field. In this relation fish has the advantage for shelter and feeding, while rice has the privilege for luxurious nutrient up take, pest reduction, and competitive advantages over weeds and micro flora (minute algae). This cumulatively results in funneling of energy and matter of rice field ecosystem towards fish and rice production to benefit the farmers.

During the study period, water temperature in all experimental plots ranged from $27 \pm 2$ to $40 \pm 2^{\circ} \mathrm{C}$ in Tanahun and Syangja, $21 \pm 2$ to $33 \pm 2{ }^{\circ} \mathrm{C}$ at Nuwakot and $27 \pm 2$ to $36.6 \pm 2^{\circ} \mathrm{C}$ at Kaski districts. Some of other experiences gained in rice-fish experiments are as follows:

\section{Rice varieties and yield in rice-fish farming}

Rice varieties such as, Janaki, Mansuli, Sabitri and Radha-4 were successfully grown with fish in the same rice field. In general, dwarf rice cultivars resistant to high water level are suitable for rice fish integration in addition to those of the deep water, tall and semi-wild rice cultivars (Mukhopadhyay et al., 1992).

Lightfoot et al. (1992) described that all interaction between rice and fish are not positive, for example early stocking of 
T.B. Gurung and S.K. Wagle / Our Nature (2005)3:1-12

Fig 2 a

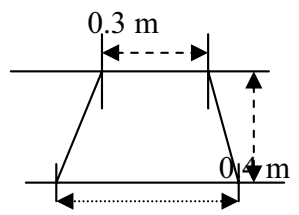

Outlet

Fig $2 \mathrm{~b}$

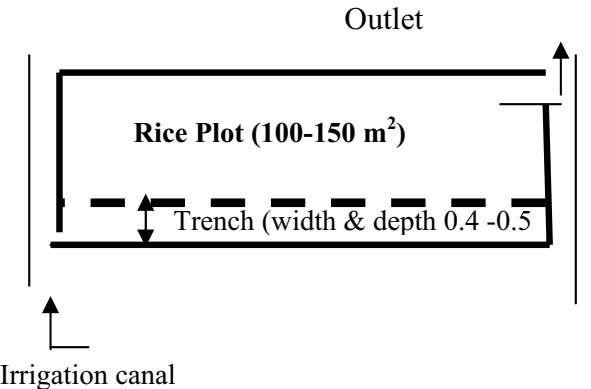

Figure 2. (a) Dimension of the rice field dike for rice fish integration (b) field sketch of rice field for rice-fish integration used in the experiments.

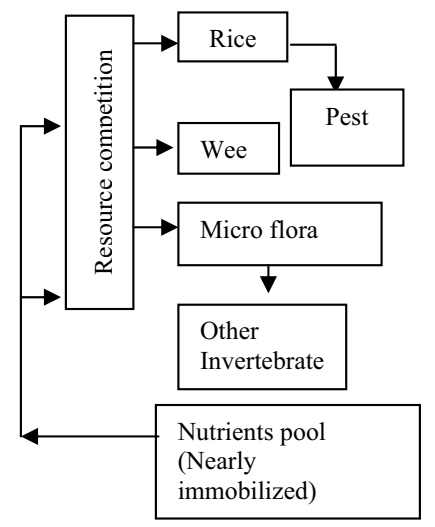

(A)

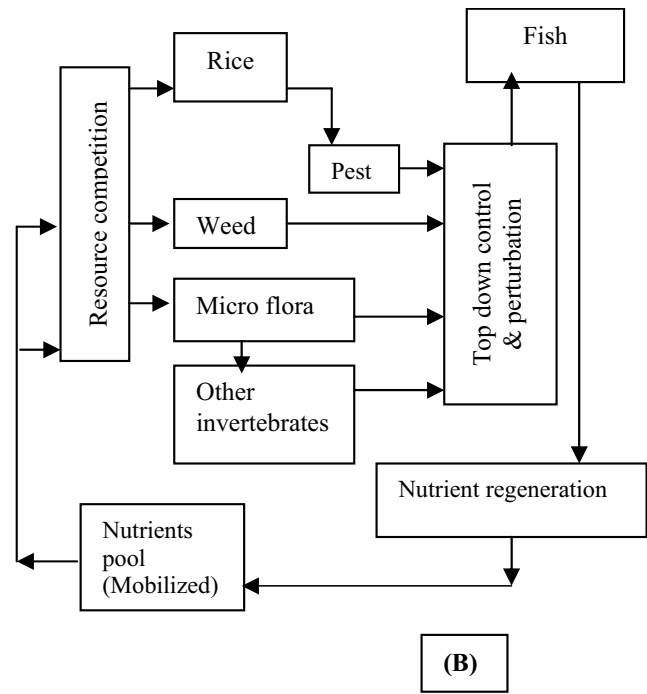

Figure 3. Schematic representation of ecological components in conventional (A), and ricefish integrated rice field (B) and pathways of material flow. 
T.B. Gurung and S.K. Wagle / Our Nature (2005)3:1-12

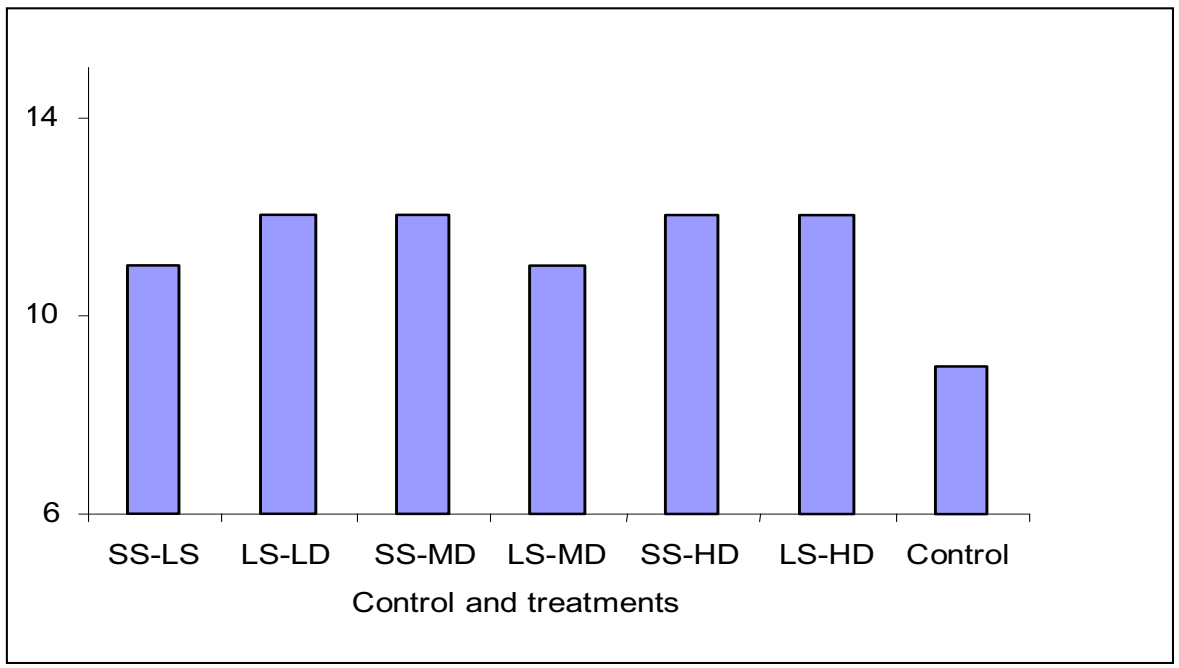

Figure 4. Number of tillers in rice plant in treatment where rice and fish were integrated and in control plots where rice was cultivated alone in Syangja.

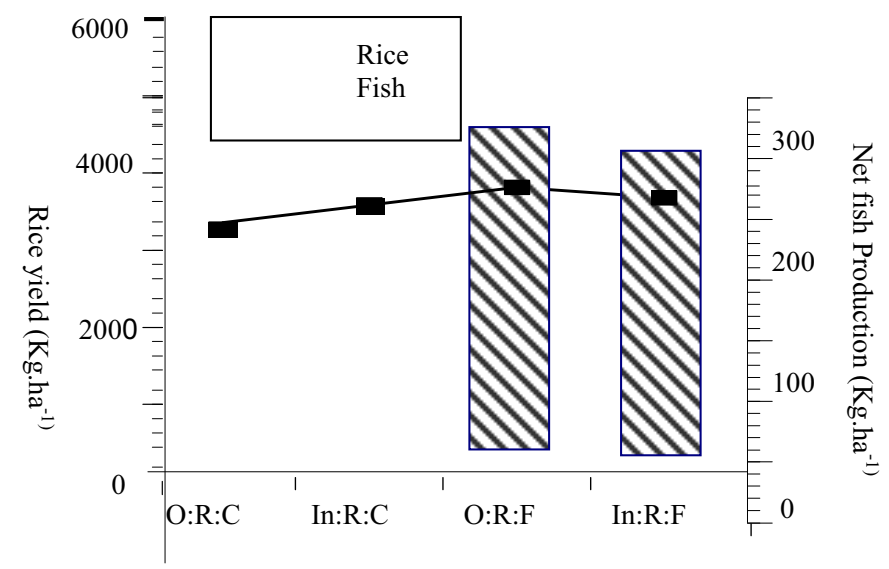

Figure 5. Rice yield and fish production with Radha-4 rice cultivars where, Or: organic manure, In: Inorganic fertilizers, R: Radha-4 rice and C: control 
T.B. Gurung and S.K. Wagle / Our Nature (2005)3:1-12

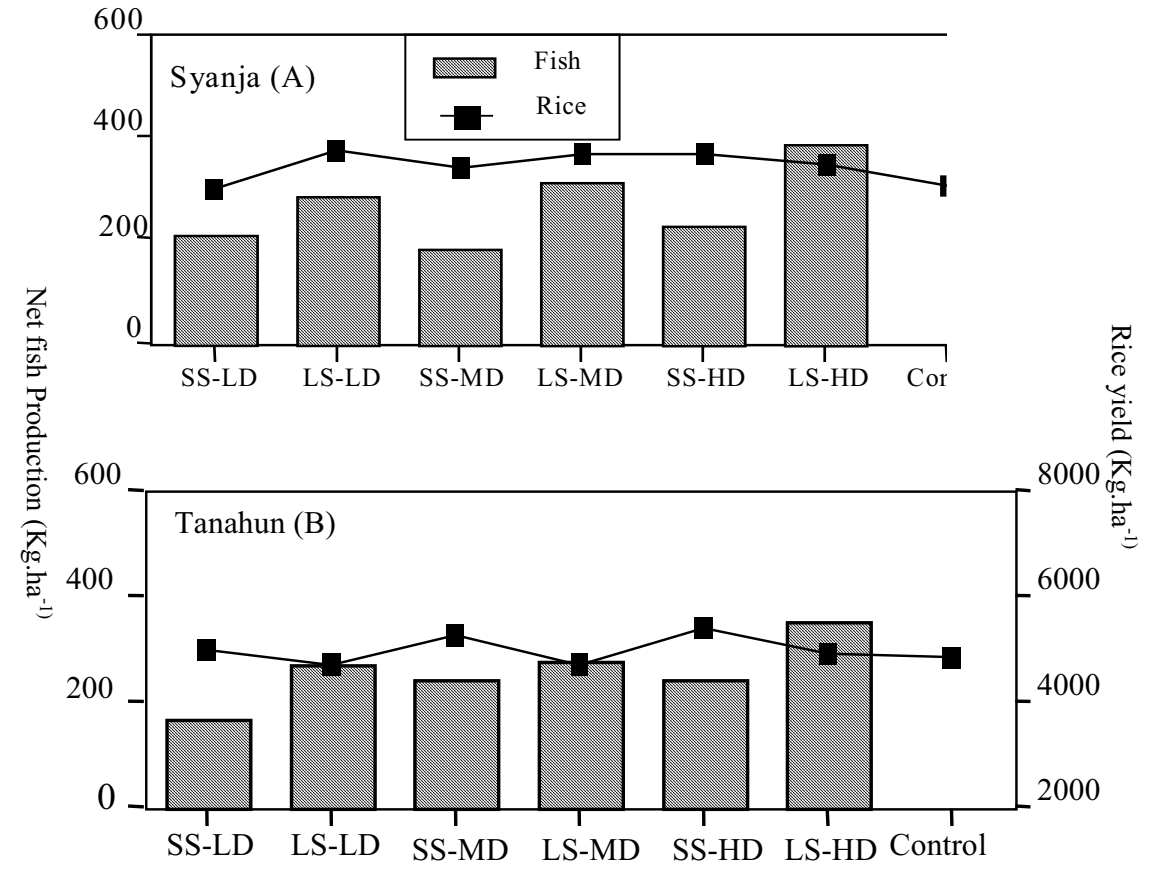

Figure 6. Rice yield and fish production in different treatments of rice-fish integration experiments at (A) Syangja and (B) Tanahun.

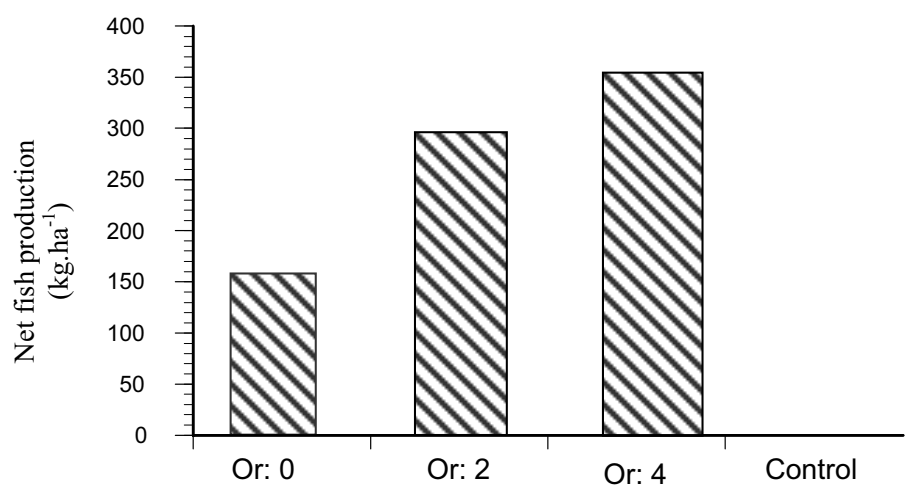

Figure 7. Fish production in treatments with feed and without feeding, rice-fish integration experiments at Nuwakot. The symbols: Or depicts organic, respectively with 0,2 and $4 \%$ body weight of feeding rates. 
T.B. Gurung and S.K. Wagle / Our Nature (2005)3:1-12
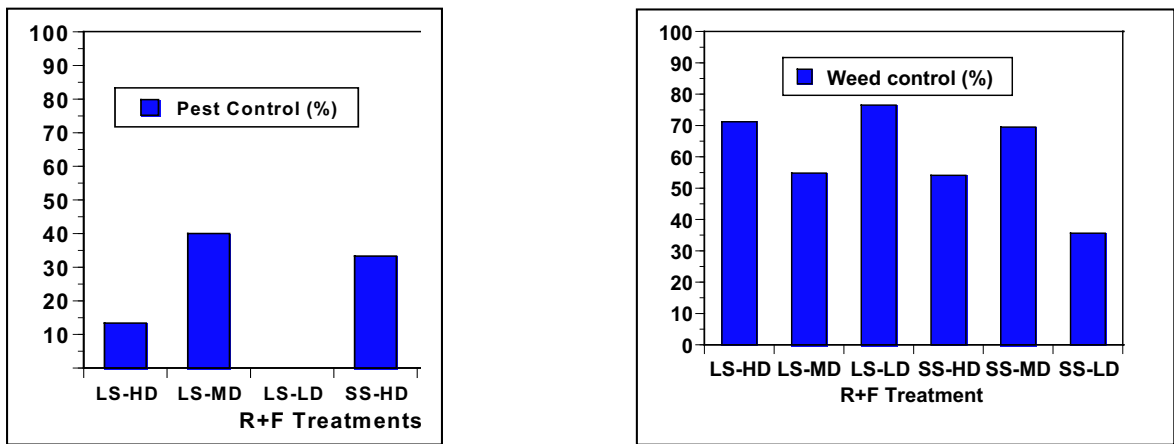

Figure 8: (A) Abundance of pest (hoppers) occurred in different rice-fish treatments in comparison to control $(100 \%)$. (B) Weed abundance in different rice-fish treatments in comparison to control $(100 \%)$

fish can uproot the rice seedling etc. He also mentioned that a definite conclusion why fish integration increase rice yield could not be clear (Lightfoot et al., 2000). One of the reasons might be healthy and well-grown rice tiller in rice-fish integration than cultivating rice alone. We found higher tiller in treatments than in control where only rice was grown (Figure 4). This suggests that higher tiller number supported higher rice yield in treatment than in control. In 0.05 ha area there could be nearly 2500 rice plants suggesting that tiller numbers can indeed bring substantial difference on rice yield.

In our study, up to $9 \%$ of higher rice yield was occurred in rice-fish integration than in control. The rice yield in control was 3.37, while $3.67 \mathrm{Mt}^{-h^{-1}}$ in treatment with Radha-4 cultivars (Figure 5). Mansuli and Sabitri also showed similar trends. Our present results of rice yield closely resemble with the national rice productivity of these varieties. The average production rate of Radha-4 is reported to be $3.2 \mathrm{Mt} \mathrm{ha}^{-1}$ (Krishi Diary, 2003). However, there are exceptions where rice yield was negligibly low in rice-fish integrated farming than cultivating rice alone in some treatments (Figure 6B). We assume that such unsubstantial results will not affect our main conclusion that average yield of the rice increases with rice fish integration than farming rice alone.

Rice-fish interaction could indeed increase the rice yield, despite of fact that $3-5 \%$ of total rice field was used for trench as fish refuse, where rice was not planted. Rothuis (1998) found no difference in rice yield between rice-fish and rice monoculture, based on the seeded rice area. Since, $11-16 \%$ area was lost due to trenches and dikes in his experiments; it clear that despite of the reduced cultivated area there was no change in yield suggesting that fish integration has indeed increased the rice yield. He also noted that the height of the rice plants in rice-fish integrated plots were relatively higher than in rice monoculture plots (Rothuis, 1998).

In fact, there are several positive effects of fish integration in rice yield. Fish regenerate nutrients such as nitrogen and phosphorus for 


\section{T.B. Gurung and S.K. Wagle / Our Nature (2005)3:1-12}

increase soil fertility; and predate over rice pest. Browsing and movement of fish in rice field during food search causes high turbidity, which prohibits photosynthesis and growth of under water weeds (Caguan, 1994; Shugen et al., 1996). Contrastingly, rice plant above the water can harvest abundant light and nutrient from under water.

\section{Appropriate fish stocking density and size}

In experiment with fish stocking density and size, higher fish production occurred with increasing stocking size and fish density. The highest fish yield $\left(529 \mathrm{~kg} \cdot \mathrm{ha}^{-1}\right.$, corresponding of $339 \mathrm{~kg} \cdot \mathrm{ha}^{-1}$ net production) was achieved where 6000 fingerlings of $20 \mathrm{~g}$ size (LS: HD treatment) were stocked in Syangja (Figure 6). In China, highest yield $\left(834 \mathrm{~kg} \mathrm{ha}^{-1}\right)$ achieved, when 9000 common carp $\mathrm{ha}^{-1}$ fry were stocked, however, in that experiment the largest fish harvested was $70.8 \mathrm{~g}$ (Guanghui et al., 1996). We harvested about $90 \mathrm{~g}$ size of common carp in most treatments. The discrimination in harvested body weight might reflect the management, growing periods, stocking size, density etc. (Banghuai and Qianlong, 1996; Xieping et al., 1996).

In these experiments rice yield ranged from 4.6 to $5.7 \mathrm{Mt} \mathrm{ha}^{-}{ }^{1}$ in treatments and 4.7 to $5.1 \mathrm{Mt}$ ha- ${ }^{1}$ in controls. The average productivity of Sabitri in Nepal is $4.5 \mathrm{Mt} \mathrm{ha}^{-1}$ (Krishi Diary, 2003). Since, all the plots were irrigated and well managed, therefore slight higher production than the national average values should be considered legitimate.

III. Fish production with feeding to fish in rice-fish farming

Generally, rice yield depends on various factors such as seed quality, water level, nutrient concentration, soil texture, management, variety and diseases etc (Pokharel, 1997; Witcombe et $a l ., 2002)$. Fish growth and production in rice field also depends on food availability, space, size of fish, predation, and mortality etc. At Nuwakot, the net fish production was $354 \mathrm{~kg}$ $\mathrm{ha}^{-1}$, with a total production of $514 \mathrm{~kg} \mathrm{ha}^{-1}$ in treatment with organic manure where $4 \%$ of feed was supplied (Figure 7). Almost similar results was obtained with inorganic fertilizers and feeding treatments. These results are within the range reported in many studies in various countries (Halwart, 1998; Rothuis, 1998; Jintong, 1996).

Common carp can be grown without supplementary feed in rice field by allowing them to access the whole rice field as their grazing ground (Figure 7). It is therefore essential to raise the water level in rice field. Sometimes fish may be restricted to the trench due to low water level. In such case, if fish cannot access the main parts of the rice field for grazing, affectivity of fish for weed and pest control will be questionable, resulting in poor production of rice and fish.

\section{Fish as IPM tools in rice field}

Many studies showed that fish in rice fields could be a part of the integrated pest management tool (Cagauan, 1994; Xieping et al., 1996; De la Cruz et al., 1992; De la Cruz, 1994). Our study showed that in general, number of hoppers visited in rice-fish integrated plot was lower than in control (Figure 8A). Weeds may play the role of secondary host for many harmful pests because, high water table maintained in the rice field could destroy the egg and larval stages of pest. Thus, the rice-fish integration can reduce pest in rice field.

\section{Role of fish for weed control}

Abundance of weeds in rice field substantially decreased, where fish were 


\section{T.B. Gurung and S.K. Wagle / Our Nature (2005)3:1-12}

integrated (Figure 8B). One of the main reasons of weed infestation in rice field is due to insufficient water level and abundance nutrient resource. Usually, weed starts to infest after 4-5 weeks of rice plantation depending on availability of light and nutrients. The removal of weeds is necessary part of the rice field management for obtaining substantial yield. In general, weeds are uprooted at least three times in a season. But, in rice-fish integrated rice field weeds are not needed to remove so often because fish can consume and destroy some weeds.

\section{Role of fish for bioturbation}

In water-sediment interface mostly a thin layer of organic matter is deposited, which contains high nutrient concentration and low dissolved oxygen than the water upper lying (Brönmark and Hansson, 1998). Usually small organisms, which can sustain low oxygen level, inhabit this layer. The activities of small animals can oxygenate the underlying water, thus changes the water quality. This process is known as bioperturbation (Brönmark and Hansson, 1998). If bottom feeder fish are introduced in such a system, their activities in search of food substantially increase dissolved oxygen. These are known to accelerate microorganisms' activities by which usable nutrients are regenerated. Perturbation by fish in rice field is therefore considered as one of the seasons for increasing rice productivity in rice-fish integrated farming.

\section{Conclusion}

Several studies showed that rice fish integration could be one of the best ecological methods to enhance productivity. The use of fish in rice field could substantially reduce abuse of insecticides on rice field. As a biological control agent of weed, insect, snail, and other diseases in rice field, integration of fish could be one of the attractive and safest alternatives over pesticides. Therefore, focus on wider scale adoption of rice-fish farming for ecological, economical, and social benefits should be emphasized in all rice growing countries.

\section{Acknowledgment}

Dr. William-Jones and Dr. John Abington improved the English. Hill Agriculture Research Program (HARP) funded this study under the project code PP: 097/99 and PP: 71/99UP. Thanks are also to Dr. A.K. Rai, Mr. J.D. Bista and Dr. S.B. Mathema for encouragement and support.

\section{References}

Ali, A.B. 1992. Rice-fish farming development method in Malaysia: Past, present and future. In: Rice-fish research and development in Asia, (Eds. C.R. De la Cruz, C. Lightfoot, B.A. Costa Pierce, V.R. Carangal and M.P. Bimbao). ICLARM Conf. Proc. 24: 457.

Arce, R.G. and C.R. De La Cruz 1978. Improved rice-fish culture in Philippines. In: Proceeding of International Commission on Irrigation and Drainage. Second Regional Afro-Asian Conference, ICID Technical Paper 10: 136-145.

Banghuai, W. and Z. Qianlong 1996. New techniques for raising fish in flooded rice fields. In: Rice-fish culture in China, (Ed. K.T. MacKay). IDRC. pp. 240

Barker, R. and D. Dawe 2000. The Asian rice economy in transition. In: Rice research and production in the 21st century: symposium honoring Robert $F$. Chandler, Jr. (Ed. W.G. Rockwood). International Rice Research Institute, Los Baños, Philippines. pp. 45-77.

Brönmark, C. and L-A. Hansson. 1998. The biology of lakes and ponds. Oxford University Press.

Cagauan, A.G. 1994. Overview of the potential roles of pisciculture on pest and disease control and nutrient management in rice fields. In: Seminar on the management of integrated ecosystems in tropical areas, (Eds. J.J. Symoens and J.C. Micha). Technical Centre for Agriculture and Rural Co-operation (CTA), Royal Academy of Overseas Sciences (Brussels). pp. 203-244

Cagauan, A.G. and R.G. Arce 1992. Overview of 


\section{T.B. Gurung and S.K. Wagle / Our Nature (2005)3:1-12}

pesticides use in rice-fish farming in South-east Asia. In: Rice-fish research and development in Asia, (Eds. C.R. De la Cruz, C. Lightfoot, B.A. Costa Pierce, V.R. Carangal and M.P. Bimbao). ICLARM Conf. Proc. 24: 457

Coche, A.G. 1967. Fish culture in rice field: a worldwide synthesis. Hydrobiol. 30: 1-44.

Dasu, N. and W. Jiangu 1996. Different methods of ricefish farming. In: Rice-fish culture in China, (Ed. K.T. MacKay). IDRC. pp. 240

De la Cruz, C.R. 1994. Role of fish in enhancing rice field ecology and in integrated pest management, (Ed. C.R. De la Cruz). ICLARM Conf. Proc. 43: 50.

De la Cruz, C.R., C. Lightfoot, B.A. Costa-Pierce, V.R. Carangal and M.P. Bimbao 1992. Rice-fish research and development in Asia (Editors). ICLARM Conf. Proc. 24: 457.

Dewan, S. 1992. Rice-fish farming in Bangladesh. In: Rice-fish research and development in Asia, (Eds. C.R. De la Cruz, C. Lightfoot, B.A. Costa-Pierce, V.R. Carangal and M.P. Bimbao). ICLARM Conf. Proc. 24: 11-16.

Dutta, S.K., D. Konar, P.K. Banarjee., S.K. De, P.K. Mukhopadhya and P.K. Pandit 1986. Prospects of increasing food production in India through different systems of paddy cum fish culture in fresh water areas: a case study. Intn. Rice Comm. Newsletter 35(1): 11-39.

Edwards, P. 2000. Aquaculture, poverty impacts and livelihood. Natural Resource Perspective, ODI, Number 56, June 2000.

Fernando, C.H. 1993. Rice field ecology and fish culture: an overview. Hydrobiol. 259: 91-113.

Guanghui, C., Y. Yuguang, W. Baogan, H. Zhangxiong and L. Shengyong 1996. Demonstration of high-yield farming in rice fields. In: Rice-fish culture in China, (Ed. K.T. MacKay). IDRC. pp. 240.

Gurung, T.B. 2003. Fisheries and aquaculture activities in Nepal. Aquaculture Asia 7: 14-19.

Gurung, T.B., S.K. Wagle and J.D. Bista 2001. Rice-fish farming in Nepal (in Nepali). Sudeep Press, Pokhara, Nepal. 54p.

Gyawali, B.K. 1999. Effect of agro-chemical pesticides on environment and the health. Paper presented in the Society of environmental journalist in Nepal, 3-4 October 1999, Kathmandu, Nepal.

Halwart, M. 1998. Trends in rice-fish farming. The FAO Aquaculture Newsletter, April 1998. (18): 3-18.

Jintong, Y. 1996. Rice-fish culture and its macrodevelopment in ecological agriculture. In: Rice-fish culture in China, (Ed. K.T. MacKay). IDRC. pp. 240

Koesoemadinata, S. 1980. Pesticides as a major constraints to integrated agriculture-aquaculture farming systems. ICLARM Conf. Proc. 4: 258. Krishi Diary 2003. Rice productivity in Nepal (In Nepali). Published by Division of Agriculture Information. Department of Agriculture. HMG, Nepal.

Li, K. 1988. Rice-fish culture in Asia: A review. Aquaculture 71: 173-186.

Lightfoot, C., A.V. Dam and B. Costa-Pierce 1992. What's happening to the rice yields in rice-fish systems? In: Rice-fish research and development in Asia, (Eds. C.R. De la Cruz, C. Lightfoot, B.A. Costa-Pierce, V.R. Carangal and M.P. Bimbao). ICLARM Conf. Proc. 24: 11-16.

Little, D.C., P. Surintaraseree and N.I. Taylor 1996. Fish culture in rain fed rice fields of northeast Thailand. Aquaculture 140(4): 295-321.

Mallick, R.N. 1971. Rice in Nepal. Published by Kala Prakashan 8/38, Bhagwan Astha, Chawel, Kathmandu, Nepal. 72p.

Matteson, P.C. 2000. Insect-pest management in tropical Asian irrigated rice fields. Annual Review Entomology 5: 549-574.

Middendrop, A.J. and J.A.J. Verreth 1986. The potential and constraints to fish culture in integrated farming systems in the Lam Pao Irrigation Project, Northwest Thailand. Aquaculture 15: 63-78.

Mukhopadhayay, P.K., D.N. Das and B. Roy 1992. Onfarm research in deepwater rice-fish culture in West Bengal, India. In: Rice-fish research and development in Asia, (Eds. C.R. De la Cruz, C. Lightfoot, B.A. Costa-Pierce, V.R. Carangal and M.P. Bimbao). ICLARM Conf. Proc. 24: 11-16.

Pokharel, T.P. 1997. Rice development programme in Nepal. Intn. Rice Comm. Newsletter 46. (Food and Agriculture Organisation of United Nations, (Ed. D. V. Tran). FAO Publishing Management Group.)?

Rothuis, A. 1998. Rice-fish culture in Mekong Delta, Vietnam: constraints analysis and adaptive research. Faculty of Science, Department of Ecology and Aquaculture, Katholieke Universiteit Leven, Belgium. (D.Sc. Thesis)

Sugen, P., H. Zhechun and Z. Jicheng 1996. Ecological mechanisms for increasing rice and fish production: In: Rice-fish culture in China, (Ed. K.T. MacKay). IDRC. pp. 240

Surtida, A.P. 2000. Rice-fish culture systems. SEAFDEC. Asian Aquaculture (6): 22-23.

Torres, J., N.A. Macabole and J.R. Mercado 1992. On farm rice fish farming system research Guimba, Nueva Ecija, Phillipines. In: Rice-fish research and development in Asia, (Eds. C.R. De la Cruz, C. Lightfoot, B.A. Costa-Pierce, V.R. Carangal and M.P. 


\section{T.B. Gurung and S.K. Wagle / Our Nature (2005)3:1-12}

Bimbao). ICLARM Conf. Proc. 24: 295-300.

Witcombe, J.R., K.D. Joshi., S. Gyawali and A. Subedi 2002. An impact assessment of participatory crop improvement in the low-altitude regions of Nepal. PSP Annual Report. Section 1: Introduction and General Overview. Research Outcomes. 11p. Xieping, L., Z.X. Lin and H. Guiting 1996. Economic analysis of rice-fish culture. In: Rice-fish culture in Asia, (Ed. K.T. MacKay). IDRC. pp. 240

Xu, Y. and G. Yixian 1992. Rich-Fish Farming System Research in China. In: Rice-fish research and development in Asia, (Eds. C.R. De la Cruz, C. Lightfoot, B.A. Costa-Pierce, V.R. Carangal and M.P. Bimbao). ICLARM Conf. Proc. 24: 315-324. 